NAPOLEON BONAPARTE AND THE LEGACY OF THE FRENCH REVOLUTION 


\section{Napoleon Bonaparte and the Legacy of the French Revolution}

MARTYN LYONS

Macmillan Education 
ISBN 978-0-333-57291-7

ISBN 978-1-349-23436-3 (eBook)

DOI 10.1007/978-1-349-23436-3

(C) Martyn Lyons 1994

Softcover reprint of the hardcover 1st edition 1994

All rights reserved. For information, write:

Scholarly and Reference Division,

St. Martin's Press, Inc., 175 Fifth Avenue,

New York, N.Y. 10010

First published in the United States of America in 1994

ISBN 978-0-312-12122-8 (cloth)

ISBN 978-0-312-12123-5 (paper)

Library of Congress Cataloging-in-Publication Data

Lyons, Martyn.

Napoleon Bonaparte and the Legacy of the French Revolution / Martyn Lyons.

p. $\mathrm{cm}$.

Includes bibliographical references and index.

ISBN 978-0-312-12122-8 (cloth) — ISBN 978-0-312-12123-5 (paper)

1. Napoleon I, Emperor of the French, 1769-1821. 2. France-History-Revolution, 1789-1799-Influence. 3. France-History-Consulate and Empire, 1799-1815. 4. Napoleonic Wars, 1800-1815.

I. Title.

DC201.L96 1994

944.05'092-dc20 
Without power, ideals cannot be realised; with power, they rarely survive

Fidel Castro

My wife and I, we have the Emperor in our guts

A distillery worker in Provence, 1822 


\section{Contents}

List of Plates viii

List of Maps ix

List of Figures and Tables $\quad \mathrm{x}$

List of Documents $\quad \mathrm{xi}$

Abbreviations xii

The Revolutionary Calendar xiii

Acknowledgements xiv

1 Introduction 1

2 Bonaparte the Jacobin 5

3 Bonaparte the Republican $\quad 15$

4 The Coup of Brumaire $\quad 29$

5 France in $1800 \quad 43$

6 Republic of Notables: The Constitution of the Year $8 \quad 60$

$\begin{array}{lll}7 & \text { The Concordat } & 77\end{array}$

8 Law Codes and Lycées $\quad 94$

9 Dictatorship by Plebiscite 111

10 Opposition: The Politics of Nostalgia 129

11 The Empire in the Village 142

12 "Masses of Granite": The Sociology of an Elite 160

13 Art, Propaganda and the Cult of Personality 178

14 The Unsheathed Sword, 1: War and International
Relations, 1800-10

15 The Unsheathed Sword, 2: Britain, Spain, Russia 213

16 The Napoleonic Revolution in Europe 229

17 The Napoleonic Empire: Collaboration and Resistance 244

18 The Economy at War 260

19 Débâcle and Resurrection, 1813-15: Napoleon the
Liberal

20 Conclusion $\quad 294$

$\begin{array}{ll}\text { Notes } & 301\end{array}$

Further Reading $\quad 330$

$\begin{array}{ll}\text { Index } & 334\end{array}$ 


\section{List of Plates}

1 Cradle of the King of Rome, 1811 (Vienna, Kunsthistorisches Museum)

2 The Intervention of the Sabine Women, 1796-9: J.-L. David (Paris, Musée du Louvre)

3 Study for Bonaparte on the Bridge at Arcole, 1796:

A.J. Gros (Paris, Musée du Louvre)

4 Bonaparte Visiting the Victims of the Plague at Jaffa, 1804:

A.J. Gros (Paris, Musée du Louvre)

5 Napoleon at the Battle of Eylau, 1807: A.J. Gros

(Paris, Musée du Louvre)

6 Bonaparte Crossing the Great St Bernard, 1801-2:

J.-L. David (Vienna, Kunsthistorisches Museum)

7 Coronation of Napoleon I, 1806-7: J.-L. David

(Paris, Musée du Louvre)

8 Coronation of Napoleon (detail): J.-L. David (Paris, Musée du Louvre)

9 The Emperor in his Study in the Tuileries, 1812:

J.-L. David (Washington, DC, National Gallery of Art) 


\section{List of Maps}

2.1 Corsica and its Neighbours in the Eighteenth Century $\quad 8$

3.1 Italy on the Eve of the Revolutionary Wars 17

3.2 The Egyptian Campaign 27

9.1 Abstention Rate in Napoleonic Plebiscites 115

14.1 Europe at the Peace of Lunéville, $1801 \quad 201$

14.2 Europe in 1806, after the Treaty of Pressburg 202

14.3 Europe after the Treaty of Tilsit, $1807 \quad 209$

14.4 The French Empire in $1812 \quad 210$

19.1 Europe after the Congress of Vienna, $1815 \quad 282$ 


\section{List of Figures and Tables}

Figures

2.1 The Bonaparte Family Tree 7

5.1 Marriage Rate in France, 1801-25 48

5.2 Birth Rate in France 1801-25 48

6.1 The French Government under the Constitution of the Year $8 \quad 62$

8.1 Divorces Decreed in Rouen, 1792-1816 101

15.1 British Exports in the Continental Blockade 218

Tables

6.1 Votes in Approval of Revolutionary Constitutions 72

9.1 Plebiscites of the Consulate and Empire 113

9.2 Voting in Toulouse, 1793-1815 115

9.3 Official Reasons for Prohibition or Modification of Sampled Censorship Cases, 1799-1830 122

12.1 Socio-professional Status of the Notables in $1810 \quad 162$

12.2 Napoleon's Marshals and their Social Origins 168

12.3 Social Origins of Napoleon's Prefects 170

12.4 Grand Dignitaries of the Empire, est. 1808

14.1 The Revolutionary and Napoleonic Wars 211

14.2 Main French Victories and Defeats 212

17.1 A Provincial Labourer's Wages, 1790-1819 261 


\section{List of Documents}

3.1 Bonaparte's Policy in Egypt

6.1 Lucien Bonaparte, Minister of the Interior, Explains the Mission of the Prefects in $1800 \quad 70$

6.2 The Restoration of Order, 1800-1 75

7.1 Religious Conflicts after the Concordat 90

9.1 Instructions to Censors, 1812

9.2 A Censor's Report $\quad 125$

11.1 Lamartine Recalls his Childhood 153

13.1 The Disaster in Russia, $1812 \quad 180$

13.2 Le Roi d'Yvetot by Béranger 184

15.1 A Spanish Catechism 221

17.1 The Problem of Food Supplies 262

19.1 The Betrayal of the Generals 283 


\section{Abbreviations}

$\begin{array}{ll}\text { AmHistRev } & \text { American Historical Review } \\ \text { AM } & \text { Annales du Midi } \\ \text { AESC } & \text { Annales - économies, sociétés, civilisations } \\ \text { AhRf } & \text { Annales historiques de la Révolution française } \\ D N & \text { Tulard, Jean, Dictionnaire Napoléon (Paris: Fayard } \\ & \text { 1987) } \\ \text { FHS } & \text { French Historical Studies } \\ \text { JMH } & \text { Journal of Modern History } \\ \text { PE्FP } & \text { Past and Present } \\ \text { PSDF } & \text { Soboul, A. et al., Les Pays sous Domination francaise, } \\ & \text { 1799-1814 (Paris: Centre de documentation universi- } \\ & \text { taire, 1968) } \\ \text { PCRE } & \text { Proceedings of the Consortium on Revolutionary Europe, } \\ & \text { 1770-1850 } \\ R E & \text { Revue économique } \\ R H & \text { Reoue historique } \\ \text { Rhmc } & \text { Revue d'histoire moderne et contemporaine }\end{array}$




\section{The Revolutionary Calendar}

The revolutionary calendar was introduced by decree in October 1793 , and remained officially in operation untion 1806 . Every month had thirty days, and the new months were named as follows:

$$
\begin{array}{ll}
\text { Vendémaire } & =22 \text { September-21 October } \\
\text { Brumaire } & =22 \text { October-20 November } \\
\text { Frimaire } & =21 \text { November-20 December } \\
\text { Nivôse } & =21 \text { December-19 January } \\
\text { Pluviôse } & =20 \text { January-18 February } \\
\text { Ventôse } & =19 \text { February-20 March } \\
\text { Germinal } & =21 \text { March-19 April } \\
\text { Floréal } & =20 \text { April-19 May } \\
\text { Prairial } & =20 \text { May-18 June } \\
\text { Messidor } & =19 \text { June-18 July } \\
\text { Thermidor } & =19 \text { July-17 August } \\
\text { Fructidor } & =18 \text { August-16 September }
\end{array}
$$

Year 1 of the Republic began retrospectively on 21 September 1792, in the Gregorian calendar, and

Year 2 was the equivalent of 22 September 1793-21 September 1794 Year 3

Year 4 22 Sepember 1794-21 September 1795

Year 5 22 Sepember 1795-21 September 1796 Year 6 Year 7 22 Sepember 1796-21 September 1797 22 Sepember 1797-21 September 1798 Year 8 22 Sepember 1798-21 September 1799

Year 9

Year 10 22 Sepember 1799-21 September 1800 Year 11 Year 12 Year 13 Year 14 22 Sepember 1800-21 September 1801 22 Sepember 1801-21 September 1802 22 Sepember 1802-21 September 1803 22 Sepember 1803-21 September 1804 22 Sepember 1804-21 September 1805 22 Sepember 1805-21 September 1806 


\section{Acknowledgements}

The author and publishers are grateful for permission to reproduce copyright material for the following:

Armand Colin Éditeur for diagrams from "Mariages et Naissances sous le Consulat et l'Empire" by A. Armengaud in the journal Revue d'histoire moderne et contemporaine (vol. 17, 1970).

Constable Publishers for a map from Pasquale Paoli: An Enlightened Hero by Peter Adam Thrasher.

Cambridge University Press for maps from France under the Directory by Martyn Lyons.

Hachette for maps copied from La Révolution, 1770-1880, by François Furet, () Hachette, 1988.

HarperCollins Publishers, Inc. for a table from The Napoleonic Revolution by Robert B. Holtman. Text Copyright (C) 1967 by Robert B. Holtman. Maps and charts copyright (C) 1967 by J.P. Lippincott Company. Reprinted by permission.

Librairie Droz SA for a map from Le Plebiscite des Cent-Jours, 1815 by F. Bluche.

Oxford University Press for a diagram from Family Breakdown in late 18th Century France: Divorces in Rouen, 1792-1803 (1980) by Roderick Phillips.

Every effort has been made to contact all the copyright-holders, but if any have been inadvertently omitted the publishers will be pleased to make the necessary arrangement at the earliest opportunity. 